
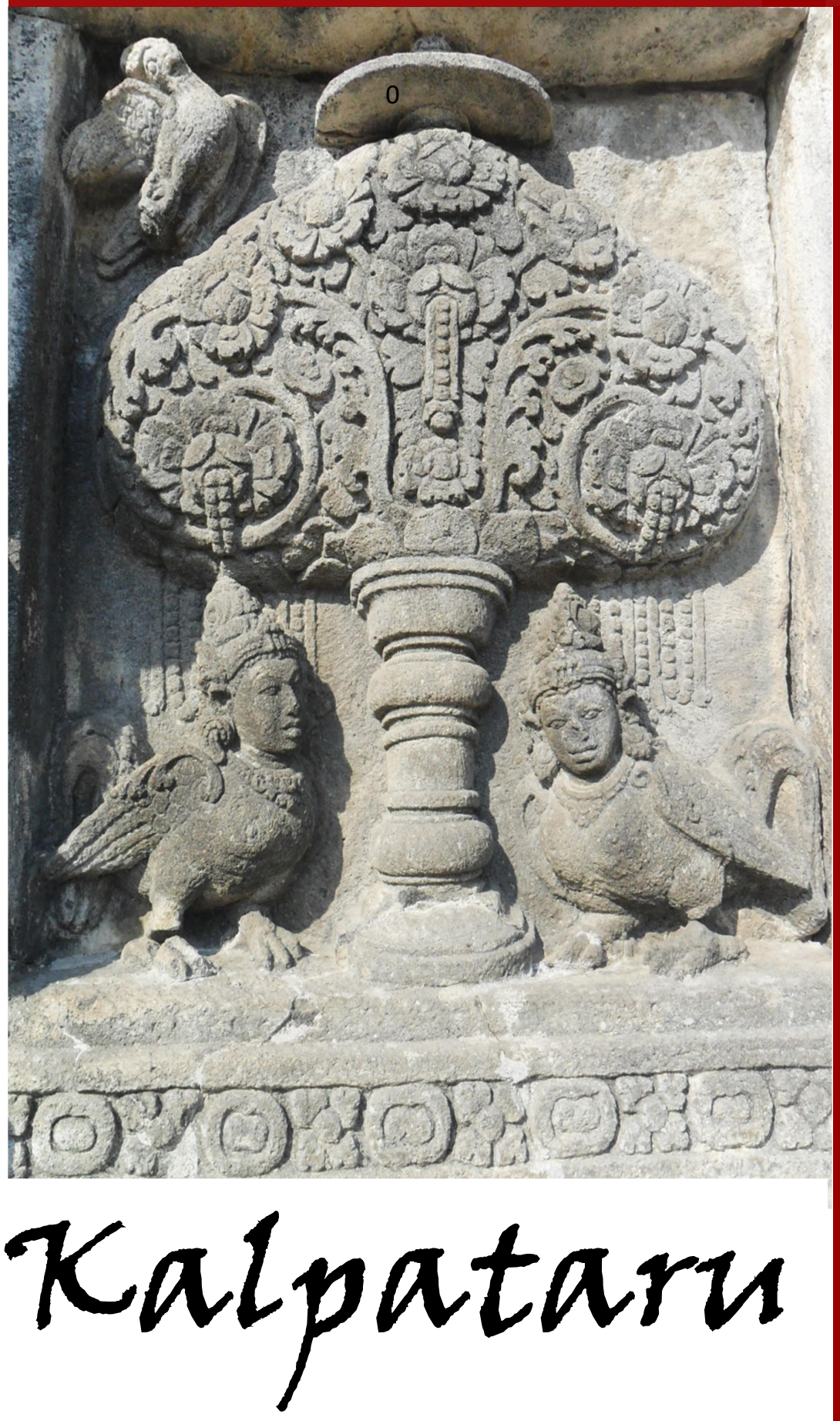

\author{
JURNAL SEJARAH DAN \\ PEMBELAJARAN SEJARAH
}

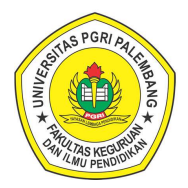

Program Studi Pendidikan Sejarah Jurusan Pendidikan IPS

Fakultas Keguruan dan IImu Pendidikan Universitas Persatuan Guru Republik Indonesia Palembang
Pengaruh Model Pembelajaran Student Facilitator and Explaining Terhadap Hasil Belajar Siswa Pada Mata Pelajaran Sejarah Kelas $X$ di SMA Negeri 3 Palembang

Sarinah, Nur Ahyani, Ahmad Zamhari

Pengaruh Model Pembelajaran Berbasis Masalah (PBM) Terhadap Hasil Belajar Siswa Pada Mata Pelajaran IPS Terpadu (Sejarah) Kelas VIII di SMP Negeri 2 Palembang

Neka Dapistri, Nur Ahyani, Ahmad Zamhari

Penerapan Media Pembelajaran Menggunakan Google Earth Dalam Materi Kondisi Masyarakat Indonesia Pada Masa Penjajahan Terhadap Hasil Belajar Siswa Pada Mata Pelajaran IPS Terpadu di SMP Quraniah Palembang

Tri Nur Ariani, Eva Dina Chairunisa, Ida Suryani

Perkembangan Sosial Budaya Suku Jawa di Desa Kapasan Tegalrejo BK $X$ Kecamatan Belitang Kabupaten Ogan Komering Ulu Timur Sebagai Sumber Pembelajaran Sejarah di SMA Muhammadiyah 2 Karang Tengah

Ratna Puspita Dewi, Sukardi, Mirza Fansyuri

Pengembangan E-Modul Pembelajaran Sejarah Tokoh-Tokoh Pembangunan

Susi Susanti, Eva Dina Chairunisa

Peran Pendidikan Sejarah Dalam Membentuk Karakter Bangsa

Sukardi, Jeki Sepriady

Sejarah Pengajaran Mantra Melayu di Tengah Perubahan Masyarakat Besemah Muhamad Idris, Eva Dina Chairunisa, Jeki Sepriady

Pengembangan Media Audio Visual Sejarah Kolonialisme Barat di Indonesia Materi Benteng Marlborough Bengkulu Hamza Kurniawan 


\section{Kalpataru}

Jurnal Sejarah dan Pembelajaran Sejarah

Volume 6, Nomor 2, Desember 2020

\section{Chief Editor}

Drs. Sukardi, M.Pd.

\section{Editor}

Dr. Muhamad Idris, M.Pd.

Eva Dina Chairunisa, M.Pd.

Jeki Sepriady, S.Pd.

\begin{tabular}{ll}
\multicolumn{2}{c}{ Reviewer } \\
Dr. Tahrun, M.Pd. & (Universitas PGRI Palembang) \\
Drs. Supriyanto, M.Hum. & (Universitas Sriwijaya Palembang) \\
Dra. Retno Purwati, M.Hum. & (Balai Arkeologi Sumatera Selatan) \\
Dr. Nor Huda Ali, M.Ag., M.A. & (Masyarakat Sejarawan Indonesia Sumsel) \\
Dr. Budi Agung Sudarman, S.S., M.Pd. & (Balai Bahasa Provinsi Sumatera Selatan) \\
Dr. Purmansyah, M.A. & (Universitas Muhammadiyah Palembang)
\end{tabular}

Alamat Redaksi

Program Studi Pendidikan Sejarah

Fakultas Keguruan dan IImu Pendidikan Universitas PGRI Palembang

Telp. 0711-510043

Email: jurnalkalpatarusejarah@gmail.com

Website: https://jurnal.univpgri-palembang.ac.id/index.php/Kalpa 


\section{Kalpataru}

JURNAL SEJARAH DAN

PEMBELAJARAN SEJARAH

Terbit dua kali setahun pada Juli dan Desember

Diterbitkan oleh:

Program Studi Pendidikan Sejarah

Jurusan Pendidikan IPS

Fakultas Keguruan

dan IImu Pendidikan

Universitas PGRI Palembang

\section{Gambar Cover:}

Pohon Kalpataru

Candi Prambanan

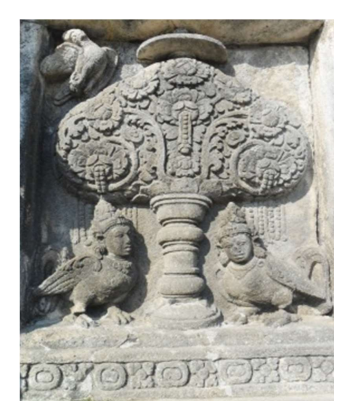

Koleksi: Muhamad Idris 


\section{DAFTAR ISI}

Pengaruh Model Pembelajaran Student Facilitator and Explaining Terhadap Hasil Belajar Siswa Pada Mata Pelajaran Sejarah Kelas X di SMA Negeri 3 Palembang

Sarinah, Nur Ahyani, Ahmad Zamhari 83-89

Pengaruh Model Pembelajaran Berbasis Masalah (PBM) Terhadap Hasil Belajar Siswa Pada Mata Pelajaran IPS Terpadu (Sejarah) Kelas VIII di SMP Negeri 2 Palembang

Neka Dapistri, Nur Ahyani, Ahmad Zamhari..... 90-95

Penerapan Media Pembelajaran Menggunakan Google Earth Dalam Materi Kondisi Masyarakat Indonesia Pada Masa Penjajahan Terhadap Hasil Belajar Siswa Pada Mata Pelajaran IPS Terpadu di SMP Quraniah Palembang

Tri Nur Ariani, Eva Dina Chairunisa, Ida Suryani $96-101$

Perkembangan Sosial Budaya Suku Jawa di Desa Kapasan Tegalrejo BK X Kecamatan Belitang Kabupaten Ogan Komering Ulu Timur Sebagai Sumber Pembelajaran Sejarah di SMA Muhammadiyah 2 Karang Tengah

Ratna Puspita Dewi, Sukardi, Mirza Fansyuri. $102-109$

Pengembangan E-Modul Pembelajaran Sejarah Tokoh-Tokoh Pembangunan Pacsa Kemerdekaan di Sumatera Selatan

Susi Susanti, Eva Dina Chairunisa 110-113

Peran Pendidikan Sejarah Dalam Membentuk Karakter Bangsa

Sukardi, Jeki Sepriady $114-117$

Sejarah Pengajaran Mantra Melayu di Tengah Perubahan Masyarakat Besemah Muhamad Idris, Eva Dina Chairunisa, Jeki Sepriady..... 118-127

Pengembangan Media Audio Visual Sejarah Kolonialisme Barat di Indonesia Materi Benteng Marlborough Bengkulu

Hamza Kurniawan. 128-135 
Kalpataru, Volume 6, Nomor 2, Desember 2020 (128-135)

\title{
PENGEMBANGAN MEDIA AUDIO VISUAL SEJARAH KOLONIALISME BARAT DI INDONESIA MATERI BENTENG MARLBOROUGH BENGKULU
}

\author{
Hamza Kurniawan \\ Guru IPS Terpadu di SMP Negeri 36 PKLK Kaur \\ Email: hamzahkedurang@gmail.com
}

\begin{abstract}
ABSTRAK
Media audio visual adalah bentuk multimedia. Multimedia merupakan salah satu media yang dapat digunakan dalam proses pembelajaran. Berdasarkan observasi yang dilakukan di SMA Negeri 4 Palembang, dilihat dari kegiatan pembelajaran pada mata pelajaran sejarah masih belum memaksimalkan multimedia, hal ini disebabkan antara lain guru dalam proses pembelajaran masih menggunakan media pembelajaran yang masih berbentuk visual, untuk dikategorikan sebagai media hal tersebut belum mencangkup materi secara keseluruhan. Media audio visual ini dipilih untuk mengatasi permasalahan tersebut, dengan pertimbangan untuk memanfaatkan fasilitas yang telah tersedia di SMA Negeri 4 Palembang. Tujuan pengembangan media ini adalah menghasilkan suatu produk media pembelajaran sejarah khususnya materi Sejarah Kolonialisme Barat di Indonesia Materi Benteng Marlborough Bengkulu dapat dijadikan alternatif dalam pencapaian tujuan pembelajaran. Penelitian ini menggunakan model perkembangan melalui sepuluh tahap berikut: (1) penelitian dan pengumpulan informasi, (2) perencanaan, (3) mengembangkan awal dari produk, (4) pengujian lapangan awal, (5) revisi awal produk, (6) uji coba pertama, (7) perbaikan dan penyempurnaan produk, (8) validasi produk, (9) revisi produk akhir, (10) menyebarluaskan produk. Hasil pengembangan media audio visual tergolong baik, meliputi penilaian dari media berada pada kriteria baik, penilaian dari isi media baik serta penilaian dari guru mata pelajaran sejarah di sekolah yang berada pada kriteria baik.
\end{abstract}

Kata Kunci: Sejarah Lokal, Benteng Marlborough, Media Pembelajaran.

\section{A. PENDAHULUAN}

Dunia pendidikan abad 21 tidak dapat dilepaskan dengan perkembangan teknologi pada umumnya. Berbagai perangkat pendidikan dan sarana pendidikan yang modern turut mendukung optimalisasi proses pembelajaran, baik ditingkat sekolah maupun dalam kehidupan sehari-hari. Perkembangan teknologi khususnya teknologi informasi dan komunikasi banyak menawarkan berbagai kemudahan-kemudahan dalam pembelajaran (Haryoko, 2012:1).

Di masa pandemi Covid-19 ini, media pembelajaran memiliki peranan penting dalam menunjang kualitas proses belajar mengajar. Media juga dapat membuat pembelajaran lebih menarik dan menyenangkan. Salah satu media pembelajaran yang sedang berkembang saat ini adalah media audio visual (Purwono, 2014:127128). Media audio visual dalam pembelajaran dimaksudkan sebagai bahan yang mengandung pesan dalam bentuk audio dan visual yang dapat merangsang fikiran, perasaan, perhatian, dan kemauan peserta didik sehingga dapat terjadi proses pembelajaran efesien dan efektif (Riyanto, 2018:24).

Bengkulu sebagai salah satu daerah penghasil lada di daerah Kepulauan Nusantara, telah menjadi daya tarik tersendiri bagi bangsabangsa Barat untuk datang dan mengadakan monopoli perdagangan terhadap hasil bumi tersebut. Pada saat kedatangan pemerintahan Inggris di Bengkulu, kompeni Inggris EIC diizinkan bermukim di daerah yang cukup luas di muara sungai Bengkulu dan membuat lokasi pemerintahan yang kuat guna melindungi pemerintahan Inggris dari serangan luar dalam kaitan ekspor lada. Permukiman ini terletak di tepian Selatan muara sungai Bengkulu, yang berdekatan dengan letak bekas kerajaan Serut di dekat sebuah bukit yang sekarang lokasinya berada di pasar Bengkulu (Siddik,1996:35).

Sejak tahun 1685, perusahaan dagang English East Indian Company (EIC) Inggris telah berhasil mencapai Sumatera khususnya di Bengkulu untuk mengembangkan usaha penanaman lada. Inggris menjadikan Bengkulu sebagai pusat bisnisnya di Sumatera. Selama pemerintahan Inggris di Bengkulu status kekuasaan Inggris mengalami perubahan terbagi menjadi tiga periode: pertama, selama dominasi kompeni Inggris di Bengkulu telah mengalami perubahan status pemerintahan sebanyak tiga kali pertama status administrasi wilayah Bengkulu pada periode 16851703 adalah sub ordinate (wilayah bawahan) 
pemerintahan Inggris yang berpusat di Madras (India), kedua pada periode 1703-1785 status wilayah Bengkulu menjadi Presidensi yang diperitah langsung seorang Gubernur, ketiga pada priode 1785-1825 status wilayah Bengkulu menjadi Residensi yang diperintah oleh residen tetap di bawah pemerintahan Inggris yang berkedudukan di Benggala, India.

Salah satu tokoh pemerintahan Inggris yang berpengaruh di Bengkulu bernama Benyamin Bloome berhasil membangun pemerintahan yang baru di Bengkulu, pada tahun 1685-1713 Benyamin Bloome dijadikan sebagai kepala kantor dagang EIC di Bengkulu, pada masa pemerintahannya perdagangan semakin bertambah ramai dan maju dengan pesat, dalam waktu yang singkat banyaklah rumah dan toko-toko didirikan di sekitar perkampungan Inggris, sehingga bandar kecil Bengkulu berkembang pesat dan menjadi sebuah kota kecil dagang dengan beranaka ragam penduduk (Siddik, 1996:35).

Pada saat kolonialisme Inggris di Indonesia, wilayah kekuasaan Inggris tidak hanya sebatas wilayah Bengkulu, kantor-kantor dagangnya meliputi wilayah Indonesia seperti Sukadana (Kalimantan Barat), Makassar, Jayakarta, Jepara (di Jawa), Aceh, Jambi (di Sumatara) dan Bengkulu untuk dikuasai dan diambil rempah-rempahnya sehingga menguntungkan bagi Inggris.

Inggris menjadikan Bengkulu sebagai pusat pemerintahannya, dengan mendirikan benteng "Fort Marlborough" dibangun tahun 1714 hingga selesai. Inggris menjadikan Fort Marlborough tidak hanya sekadar sebagai sebuah benteng pertahanan namun juga sebagai pusat bisnis, pusat administrasi dan tempat kedudukan para pejabat EIC, serta sekaligus sebagai salah satu areal perkebunan lada.

Fungsi dari benteng Marlborough tidak hanya sebagai benteng pertahanan pemerintahan Inggris disaat mendapat serangan dari orang-orang luar, khususnya dari VOC, tetapi di dalam benteng terdapat ruangan yang digunakan sebagai ruangan pemerintahan Inggris. Bagian atas benteng menghadap ke Samudra Hindia dan pantai Tapak Paderi, di persenjatai dengan meriam-meriam, sedangkan di bagian bawah terdapat beberapa ruangan besar dan kecil yang digunakan sebagai kamar-kamar, serdadu, ruang tahanan, gudang mesiu, perbekalan, dan ruangan kantor untuk pejabat-pejabat Inggris yang ada di Bengkulu, ruangan gubernur Inggris, di sekitar benteng terdapat parit-parit peratahanan dan tiga buah jembatan penghubung yang waktu-waktu dapat di angkat (Siddik,1996:42).
Berdasarkan permasalahan di atas, maka peneliti mencoba mengembangkan media pembelajaran audio visual sejarah kolonialisme Barat di Indonesia materi Benteng Marlborough Bengkulu. Dengan demikian diharapkan media pembelajaran ini dapat membantu siswa untuk mempelajari sejarah kolonialisme Barat di Indonesia materi Benteng Marlborough Bengkulu. Adapun tujuan dari penelitian ini adalah sebagai berikut: 1) Menghasilkan produk media pembelajaran audio visual pada materi sejarah kolonialisme Barat di Indonesia materi Benteng Marlborough Bengkulu. 2) Mengetahui efektifitas dan kemenarikan media audio visual dalam proses pembelajaran sejarah.

\section{B. METODE PENELITIAN}

Dalam penelitian ini menggunakan metode penelitian dan pengembangan (Research and Development). Research and development bertujuan untuk menghasilkan produk baru melalui proses pengembangan. Kegiatan penelitian diintegrasikan selama proses pengembangan produk, oleh sebab itu di dalam penelitian itu perlu memadukan beberapa jenis metode penelitian, antara lain jenis penelitian survei dengan eksperimen atau action research dan evaluasi. Produk penelitian dan pengembangan dalam bidang pendidikan dapat berupa model, media, peralatan, buku, modul, alat evaluasi dan perangkat pembelajaran, kurikulum, kebijakan sekolah dan lain-lain (Mulyatiningsih, 2017:161).

\section{Sumber Data}

Angket

Angket merupakan alat untuk mengumpulkan data secara tertulis berupa berbagai bentuk pertanyaan yang disusun dan disebarkan untuk mendapatkan bahan dan masukan berbagai informasi secara akurat dari responden (Rukajat, 2018:86). Dokumentasi ialah pengambilan data yang diperoleh melalui dokumendokumen. Dokumentasi ditujukan untuk memperoleh data langsung dari tempat penelitian, meliputi buku-buku yang relevan, peraturanperaturan, laporan kegiatan, foto-foto, film dokumenter, data yang relevan penelitian (Riduwan, 2016:31).

\section{Observasi}

Observasi merupakan salah satu metode pengumpulan data dimana pengumpul data mengamati secara visual gejala yang diamati serta menginterprestasikan hasil pengamatan tersebut dalam bentuk catatan sehingga validitas data 
sangat tergantung pada kemampuan observer (Widoyoko, 2018:46).

\section{Wawancara}

Wawancara merupakan salah satu teknik yang dapat digunakan untuk mengumpulkan data penelitian. Secara sederhana dapat dikatakan bahwa wawancara (interview) adalah suatu kejadian atau suatu proses interaksi antara pewawancara (interviewer) dan sumber informasi atau orang yang diwawancarai (interviewee) melalui komunikasi langsung. Dapat pula dikatakan bahwa wawancara merupakan percakapan tatap muka (face to face) antara pewawancara dengan sumber informasi, dimana pewawancara bertanya langsung tentang sesuatu objek yang diteliti dan telah dirancang sebelumnya (Yusuf, 2017:372).

\section{Teknik Analisis Data}

Teknik analisis data adalah proses mencari dan menyusun secara sistematis data yang diperoleh dari hasil wawancara, catatan lapangan, dan dokumentasi, dengan cara mengorganisasikan data ke dalam katagori, menjabarkan ke dalam unitunit, melakukan sintesa, menyusun ke dalam pola, memilih mana yang penting dan yang akan dipelajari, dan membuat kesimpulan sehingga mudah dipahami oleh diri sendiri maupun orang lain (Sugiyono, 2018:335).

Teknik analisis yang digunakan untuk mengolah data dari hasil uji coba produk.

$$
\mathrm{P}=\frac{\sum x}{\sum x i} \times 100 \%
$$

Keterangan:

$\mathrm{P}=$ Persentase

$\mathrm{X}=$ Jawaban Responden

$\mathrm{Xi}=$ Nilai Keseluruhan

\section{HASIL DAN PEMBAHASAN}

Data Hasil Validasi Media

\begin{tabular}{|c|l|}
\hline No. & \multicolumn{1}{|c|}{ Aspek yang di Evaluasi } \\
\hline 1. & $\begin{array}{l}\text { Kemenarikan pengemasan desain cover } \\
\text { pada media audio visual. }\end{array}$ \\
\hline 2. & $\begin{array}{l}\text { Kesesuaian gambar pada cover media audio } \\
\text { visual. }\end{array}$ \\
\hline 3. & $\begin{array}{l}\text { Kesesuaian pemakaian warna, dan huruf } \\
\text { yang digunakan dalam media audio visual. }\end{array}$ \\
\hline 4. & $\begin{array}{l}\text { Kemenarikan visualisasi pada media audio } \\
\text { visual }\end{array}$ \\
\hline 5. & $\begin{array}{l}\text { Kemenarikan ilustrasi gambar pada media } \\
\text { audio visual }\end{array}$ \\
\hline 6. & $\begin{array}{l}\text { Kemenarikan tampilan isi materi pada media } \\
\text { audio visual }\end{array}$ \\
\hline 7. & $\begin{array}{l}\text { Kesesuain media dengan karakteristik } \\
\text { peserta didik. }\end{array}$ \\
\hline 8. & $\begin{array}{l}\text { Kemudahan memahami uraian materi pada } \\
\text { setiap sub bahasan }\end{array}$ \\
\hline
\end{tabular}

Berdasarkan hasil penilaian pertama dari validator media terhadap media pembelajaran maka dapat dihitung persentase tingkat pencapaian media sebagai berikut:

$$
\begin{aligned}
& \mathrm{P}=\frac{\sum x}{\sum x i} \times 100 \% \\
& \mathrm{P}=\frac{27}{40} \times 100 \% \\
& \mathrm{P}=67,5 \%
\end{aligned}
$$

Berdasarkan penilaian kedua dari validator media terhadap media pembelajaran maka dapat dihitung persentase tingkat pencapaian media sebagai berikut:

$$
\begin{aligned}
& \mathrm{P}=\frac{\sum x}{\sum x i} \times 100 \% \\
& \mathrm{P}=\frac{35}{40} \times 100 \% \\
& \mathrm{P}=87,5 \%
\end{aligned}
$$

Berdasarkan penilaian pertama dan kedua dari validator media, dari aspek yang menjadi kriteria penilaian, dari penilaian pertama didapat persentase tingkat pencapaian 67,5\%, dan penilaian kedua didapat persentase tingkat pencapaian $87,5 \%$. Maka dalam penilaian kedua produk berada pada kriteria sangat layak sehingga media pembelajaran tidak perlu revisi lagi.

Data Hasil Validasi Materi 


\begin{tabular}{|c|l|}
\hline No. & \multicolumn{1}{|c|}{ Aspek yang di Evaluasi } \\
\hline 1 & $\begin{array}{l}\text { Kesesuaian materi yang disajikan audio } \\
\text { visual. }\end{array}$ \\
\hline 2 & $\begin{array}{l}\text { Kemudahan memahami materi melalui } \\
\text { media audio visual. }\end{array}$ \\
\hline 3 & $\begin{array}{l}\text { Kemenarikan/kesesuaian media audio } \\
\text { visual dengan konsep materi. }\end{array}$ \\
\hline 4 & $\begin{array}{l}\text { Bahasa yang digunakan pada media } \\
\text { audio visual. }\end{array}$ \\
\hline 5 & $\begin{array}{l}\text { Kemudahan bahasa untuk dipahami } \\
\text { dalam media audio visual. }\end{array}$ \\
\hline 6 & $\begin{array}{l}\text { Penanaman konsep pada media audio } \\
\text { visual. }\end{array}$ \\
\hline 7 & $\begin{array}{l}\text { Ketepatan tujuan pembelajaran pada } \\
\text { media audio visual. }\end{array}$ \\
\hline 8 & $\begin{array}{l}\text { Kesesuaian komponen media } \\
\text { pembelajaran sejarah dalam materi } \\
\text { sejarah kolonialisme Barat di Indonesia } \\
\text { materi Benteng Marlborough Bengkulu. }\end{array}$ \\
\hline 9 & $\begin{array}{l}\text { Kesesuaian gambar dengan penjelasan } \\
\text { dalam penjabaran. }\end{array}$ \\
\hline 10 & $\begin{array}{l}\text { Keluasan dan dalam isi media audio } \\
\text { visual. }\end{array}$ \\
\hline 11 & \begin{tabular}{l} 
Keruntutan penyajian materi. \\
\hline 12
\end{tabular} $\begin{array}{l}\text { Kejelasan materi dalam media audio } \\
\text { visual. }\end{array}$ \\
\hline 13 & Ketepatan penggunaan gambar. \\
\hline 14 & $\begin{array}{l}\text { Kesesuaian bentuk evaluasi pada media } \\
\text { audio visual. }\end{array}$ \\
\hline 15 & Validitas isi secara keilmuan. \\
\hline
\end{tabular}

Berdasarkan hasil penilaian pertama dari validator materi terhadap media pembelajaran maka dapat dihitung persentase tingkat pencapaian media sebagai berikut:

$$
\begin{aligned}
& \mathrm{P}=\frac{\sum x}{\sum x i} \times 100 \% \\
& \mathrm{P}=\frac{52}{75} \times 100 \% \\
& \mathrm{P}=69,34 \%
\end{aligned}
$$

Berdasarkan penilaian kedua dari validator materi pembelajaran terhadap media pembelajaran maka dapat dihitung persentase tingkat pencapaian media sebagai berikut:

$$
\begin{aligned}
& \mathrm{P}=\frac{\sum x}{\sum x i} \times 100 \% \\
& \mathrm{P}=\frac{72}{75} \times 100 \% \\
& \mathrm{P}=96 \% .
\end{aligned}
$$

Dari penilaian pertama didapat persentase tingkat pencapaian $69,34 \%$, dan penilaian kedua

\begin{tabular}{|c|c|}
\hline No. & Aspek yang di Evaluasi \\
\hline 1. & $\begin{array}{l}\text { Apakah media pembelajaran ini } \\
\text { memudahkan anda dalam kegiatan } \\
\text { belajar mengajar mata pelajaran } \\
\text { sejarah? }\end{array}$ \\
\hline 2. & $\begin{array}{l}\text { Apakah alat media pembelajaran ini tepat } \\
\text { digunakan dalam pembelajaran sejarah } \\
\text { khususnya materi sejarah kolonialisme } \\
\text { Barat di Indonesia materi tentang } \\
\text { Benteng Marlborough Bengkulu? }\end{array}$ \\
\hline 3. & $\begin{array}{l}\text { Bagaimana kejelasan paparan materi } \\
\text { media pembelajaran? }\end{array}$ \\
\hline 4. & $\begin{array}{l}\text { Apakah ruang lingkup materi yang } \\
\text { disajikan pada media sesuai dengan } \\
\text { tujuan pembelajaran? }\end{array}$ \\
\hline 5. & $\begin{array}{l}\text { Apakah media pembelajaran ini dapat } \\
\text { membuat siswa aktif dalam } \\
\text { pembelajaran? }\end{array}$ \\
\hline 6. & $\begin{array}{l}\text { Apakah media pembelajaran ini tepat } \\
\text { digunakan? }\end{array}$ \\
\hline 7. & $\begin{array}{l}\text { Apakah penggunaan media } \\
\text { pembelajaran ini dapat memudahkan } \\
\text { siswa dalam memahami materi? }\end{array}$ \\
\hline 8. & $\begin{array}{lll}\text { Bagaimana } & \text { kejelasan } & \text { tujuan } \\
\text { pembelajaran? } & & \\
\end{array}$ \\
\hline 9. & 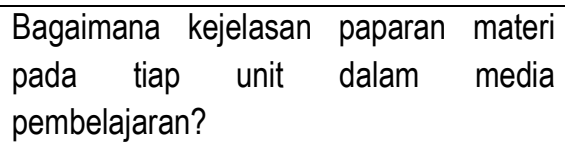 \\
\hline 10. & $\begin{array}{l}\text { Bagaimana tingkat kesesuai antara } \\
\text { gambar dengan materi? }\end{array}$ \\
\hline 11. & $\begin{array}{l}\text { Bagaimana kejelasan evaluasi dalam } \\
\text { media pembelajaran? }\end{array}$ \\
\hline 12. & $\begin{array}{l}\text { Apakah evaluasi dalam media } \\
\text { pembelajaran membantu meningkatkan } \\
\text { pemahaman siswa terhadap materi? }\end{array}$ \\
\hline 13. & $\begin{array}{l}\text { Apakah dengan menggunakan media } \\
\text { pembelajaran ini siswa termotivasi dalam } \\
\text { mengikuti pembelajaran sejarah? }\end{array}$ \\
\hline 14. & $\begin{array}{l}\text { Apakah media pembelajaran ini } \\
\text { membantu anda dalam menyampaikan }\end{array}$ \\
\hline
\end{tabular}
didapat persentase tingkat pencapaian 96\%. Maka dalam penilaian kedua produk berada pada kriteria sangat layak sehingga media pembelajaran tidak perlu revisi lagi.

Data Hasil Uji Penggunaan Media Oleh Guru 


\begin{tabular}{|c|l|}
\hline No. & \multicolumn{1}{|c|}{ Aspek yang di Evaluasi } \\
\hline & materi? \\
\hline 15. & $\begin{array}{l}\text { Apakah media ini dapat dipahami uraian } \\
\text { materinya? }\end{array}$ \\
\hline
\end{tabular}

Berdasarkan hasil penilaian pertama dari guru mata pelajaran terhadap media pembelajaran maka dapat dihitung persentase tingkat pencapaian media sebagai berikut:

$$
\begin{aligned}
& \mathrm{P}=\frac{\bar{\sum} x}{\sum x i} \times 100 \% \\
& \mathrm{P}=\frac{51}{75} \times 100 \% \\
& \mathrm{P}=68 \%
\end{aligned}
$$

Berdasarkan penilaian kedua dari guru mata pelajaran terhadap media pembelajaran maka dapat dihitung persentase tingkat pencapaian media sebagai berikut:

$$
\begin{aligned}
& \mathrm{P}=\frac{\bar{\Sigma} x}{\sum x i} \times 100 \% \\
& \mathrm{P}=\frac{66}{75} \times 100 \% \\
& \mathrm{P}=88 \%
\end{aligned}
$$

Berdasarkan penilaian pertama dan kedua dari validator media, dari aspek yang menjadi kriteria penilaian, dari penilaian pertama didapat persentase tingkat pencapaian $68 \%$, dan penilaian kedua didapat persentase tingkat pencapaian $88 \%$. Maka dalam penilaian kedua produk berada pada kriteria sangat layak sehingga media pembelajaran tidak perlu revisi lagi.

Data Hasil Uji Penggunaan Media oleh Siswa

\begin{tabular}{|c|l|}
\hline No. & \multicolumn{1}{|c|}{ Aspek yang di Evaluasi } \\
\hline 1. & $\begin{array}{l}\text { Apakah kamu merasa mudah dalam } \\
\text { memahami materi pada media ini? }\end{array}$ \\
\hline 2. & $\begin{array}{l}\text { Apakah tampilan visualisasi pada media } \\
\text { ini menarik? }\end{array}$ \\
\hline 3. & $\begin{array}{l}\text { Bagaimana kejelasan paparan materi } \\
\text { media ini? }\end{array}$ \\
\hline 4. & $\begin{array}{l}\text { Apakah suara yang terdapat dalam } \\
\text { media ini menarik? }\end{array}$ \\
\hline 5. & Apakah suara dalam media ini jelas? \\
\hline 6. & Apakah tulisan dalam media ini jelas? \\
\hline 7. & Apakah tampilan materi menarik? \\
\hline 8. & $\begin{array}{l}\text { Apakah kamu termotivasi untuk belajar } \\
\text { dengan lebih baik ketika menggunakan } \\
\text { media ini? }\end{array}$ \\
\hline 9. & $\begin{array}{l}\text { Apakah kamu memiliki rasa ingin tahu } \\
\text { menggunakan media ini? }\end{array}$ \\
\hline 10. & $\begin{array}{l}\text { Apakah kamu merasa senang ketika } \\
\text { menggunakan media ini? }\end{array}$ \\
\hline
\end{tabular}

Berdasarkan hasil uji coba pertama dari siswa kelas XI IPA 3 terhadap media pembelajaran maka dapat dihitung persentase tingkat pencapaian media sebagai berikut:

$$
\begin{aligned}
& \mathrm{P}=\frac{\bar{\Sigma} x}{\sum x i} \times 100 \% \\
& \mathrm{P}=\frac{1133}{1800} \times 100 \% \\
& \mathrm{P}=62,94 \%
\end{aligned}
$$

Berdasarkan hasil uji coba kedua dari siswa kelas XI IPA 3 di SMA Negeri 4 Palembang terhadap media pembelajaran maka dapat dihitung persentase tingkat pencapaian media sebagai berikut:

$$
\begin{aligned}
& \mathrm{P}=\frac{\sum x}{\sum x i} \times 100 \% \\
& \mathrm{P}=\frac{1572}{1800} \times 100 \% \\
& \mathrm{P}=87,34 \%
\end{aligned}
$$

Berdasarkan penilaian pertama dan kedua dari seluruh siswa kelas XI IPA 3 yang berjumlah 36 siswa di SMA Negeri 4 Palembang, dari aspek yang menjadi kriteria penilaian, dari penilaian pertama didapat persentase tingkat pencapaian $62,94 \%$, dan penilaian kedua didapat persentase tingkat pencapaian $87,34 \%$. Maka dalam penilaian kedua produk berada pada kriteria sangat layak sehingga media pembelajaran tidak perlu revisi lagi.

Pembahasan Cara Mengembangkan Media Audio Visual

\section{Mengkaji KD dan KI}

Materi pembelajaran audio visual mengenai sejarah kolonialisme Barat di Indonesia materi tentang Benteng Marlborough Bengkulu ini terkait dengan 3.1 Menganalisis proses masuk dan perkembangan penjajahan bangsa Eropa (Portugis, Spanyol, Belanda, Inggris) ke Indonesia. 4.1 Mengolah informasi tentang proses masuk dan perkembangan penjajahan bangsa Eropa (Portugis, Spanyol, Belanda, Inggris) ke Indonesia dan menyajikannya dalam bentuk cerita sejarah sesuai dengan kurikulum 2013 yang ada di kelas XI semester ganjil.

\section{Menentukan Poin Materi}

Poin materi yang diambil dari pembuatan media audio visual ini dilakukan satu rangkaian dengan $\mathrm{KI}$ dan $\mathrm{KD}$, dan materi. Hal tersebut dikarenakan dalam membuat poin-poin materi yang akan disampaikan harus sudah terencana. Poinpoin materi diturunkan dari $\mathrm{KI}$ dan $\mathrm{KD}$ dan materi. Pada materi sejarah kolonialisme Barat di Indonesia materi tentang Benteng Marlborough Bengkulu terdapat beberapa materi yang pertama 
tentang sejarah masuknya Inggris ke Bengkulu dan yang kedua tentang Benteng Marlborough Bengkulu.

\section{Mengkaji Media}

Dalam penelitian ini peneliti menggunakan media audio visual untuk dikembangkan. Dalam pembuatan media ini dibutuhkan cara pembuatan media, dan dalam hal ini yang perlu dilakukan pada tahap awal yaitu:

\section{Mengumpulkan Informasi}

Berdasarkan hasil observasi analisis kebutuhan yang dilakukan oleh peneliti, maka diperoleh beberapa informasi bahwa media pembelajaran yang digunakan yakni berupa media visual. Media visual yang digunakan guru adalah media gambar dan jarang sekali menggunakan benda kontret. Selain melakukan observasi, peneliti juga melakukan wawancara dengan guru sejarah senior di SMA Negeri 4 Palembang yakni lbu Hilya Baity Akbari, S.Pd., M.Si. hal tersebut dilakukan sebagai salah satu instrumen pengumpulan data pada tahap analisis kebutuhan ini, sehingga dari hasil wawancara dengan Hilya Baity Akbari, S.Pd., M.Si. diantaranya, meski menggunakan media terkadang peserta didik tetap tidak memusatkan perhatian pada guru dan belum memahami materi. Buku yang digunakan yakni buku cetak pembelajaran sejarah.

\section{Desain Media}

Setelah mengetahui kebutuhan lapangan dari data yang diperoleh pada saat tahap analisis kebutuhan, maka peneliti melakukan perencanaan dalam mengembangkan media pembelajaran. Tahap pertama yang dilakukan pengembangan dalam perancangan media yaitu sebagai berikut:

1. Pemilihan Judul merupakan tahap yang dilakukan oleh peneliti setelah melakukan proses perumusan masalah yang terjadi di dalam proses pembelajaran.

2. Pembuatan Konsep dilakukan setelah proses pemilihan judul penelitian. Dalam pembuatan konsep ini, juga diperlukan sebuah gagasan yang mana dengan adanya ide yang ada dapat menghasilkan sebuah konsep baru yang nantinya dapat menghasilkan sebuah draft produk yang bertujuan untuk membantu mengatasi masalah yang timbul dari sebuah analisis kebutuhan yang dilakukan di sekolah.
3. Pembuatan Story Board Storyboard secara harfiah berarti dasar cerita. Storyboard adalah area berseri dari sebuah gambar sketsa yang digunakan sebagai alat perencanaan untuk menunjukan secara visual bagaimana aksi dari sebuah berlangsung. Storyboard merupakan naskah yang dituangkan dalam bentuk gambar. Storyboard yaitu penjelasan bagaimana cara seseorang akan membuat suatu proyek. Jika diumpamakan sebagai pembuatan film, maka bisa dibilang bahwa storyboard adalah skenario film tersebut.

4. Pemilihan Software (perangkat lunak) adalah kumpulan perintah yang dieksekusi oleh mesin komputer dalam menjalankan pekerjaannya. Software dibuat untuk menjalankan hardware komputer agar dapat berjalan sesuai fungsi yang diinginkan.

5. Pembuatan Animasi adalah gambar bergerak berbentuk dari sekumpulan objek (gambar) yang disusun secara beraturan mengikuti alur pergerakan yang telah ditentukan pada setiap pertambahan hitungan waktu yang terjadi. Pada proses pembuatannya animator harus menggunakan logika berfikir untuk menentukan alur suatu objek dari keadaan awal hingga keadaan akhir objek tersebut.

\section{Melakukan Validasi Media dan Revisi}

Berdasarkan validasi yang dilakukan maka media pembelajaran produk pengembangan tidak perlu mendapatkan revisi dan perbaikan. Akan tetapi komentar dan saran dari penilaian media akan dijadikan bahan pertimbangan untuk menyempurnakan media pembelajaran sehingga produk pengembangan yang dihasilkan akan menjadi semakin baik. Setelah melakukan beberapa penilaian validasi maka media ini secara keseluruhan dinyatakan valid dan layak untuk digunakan, maka tahap terakhir adalah produksi media pembelajaran audio visual mata pelajarah sejarah dengan judul sejarah kolonialisme Barat di Indonesia materi tentang Benteng Marlborough Bengkulu dapat digunakan kapan saja.

\section{SIMPULAN}

Penelitian ini menggunakan model $R \& D$ (Research \& Developmen) oleh Borg and Gall yang 
terdiri dari sepuluh tahapan. Tahap pertama yaitu tahap penelitian dan pengumpulan Informasi meliputi pemilihan sekolah, pemilihan materi dan analisis kebutuhan yang dilakukan untuk menentukan masalah dasar untuk mengembangkan media meliputi analisis siswa, analisis konsep dan analisis tujuan yang diambil agar lebih mudah dipelajari dan dipahami siswa. Tahap kedua adalah tahap perencanaan yang meliputi pemilihan media, pengulasan media yang diangkat dalam media audio visual dan pembuatan desain produk. Tahap ketiga yaitu tahap pengembangan awal produk yang menghasilkan media pembelajaran audio visual. Tahap keempat adalah tahap pengujian awal yaitu melakukan penyusunan instrumen-instrumen yang meliputi lembar validasi media, dan angket siswa. Tahap kelima yaitu tahap revisi produk awal yaitu melakukan perbaikan terhadap media audio visual. Tahap keenam yaitu tahap uji coba produk yang dilakukan di SMA Negeri 4 Palembang, uji coba dilaksanakan dengan melangsungkan proses belajar mengajar dengan menggunakan media audio visual dan disamping itu juga dilakukan pengisian angket oleh siswa. Tahap ketujuh yaitu tahap perbaikan dan penyempurnaan produk dengan melakukan revisi setelah uji coba pertama. Tahap kedelapan yaitu tahap validasi produk, pada tahapan ini dilakukan validasi oleh validator. Tahap kesembilan yaitu tahap revisi produk akhir, revisi dilakukan sesuai dengan saran masingmasing dari validator. Setelah media pembelajaran melalui tahap revisi dan dinyatakan layak uji coba maka dilakukan tahap yang kesepuluh yaitu menyebarluaskan produk. Setelah media dilakukan analisis sehingga dapat disimpulkan bahwa media audio visual yang dikembangkan memenuhi kriteria sebagai media yang baik.

Hasil validasi pengembangan media audio visual sejarah kolonialisme Barat di Indonesia materi tentang Benteng Marlborough Bengkulu memiliki tingkat kelayakan yang tinggi berdasarkan hasil validasi materi pembelajaran didapat persentase sebesar $96 \%$ yang artinya media ini sangat layak dan tidak perlu revisi.

Berdasarkan hasil penilaian validasi media didapat persentase sebesar $87,5 \%$ yang artinya media ini sangat layak dan tidak perlu revisi. Berdasarkan hasil penilaian validasi guru didapat persentase sebesar $88 \%$ yang artinya media ini sangat layak dan tidak perlu revisi. Dan berdasarkan hasil penilaian uji coba lapangan dengan siswa didapat persentase sebesar $87,34 \%$ yang artinya media ini sangat layak dan tidak perlu revisi.

\section{DAFTAR PUSTAKA}

Haryoko, S. 2012. "Efektivitas Pemanfaatan Media Audio Visual Sebagai Alternatif Optimalisasi Model Pembelajaran". dalam Edukasi Elektro. (1-9).

Mulyatiningsih, E. 2017. Metode Penelitian Terapan Bidang Pendidikan. Bandung: Alfabeta.

Purwono, J. 2014. Penggunaan Media Audio Visual Pada Mata Pelajaran IImu Pengetahuan Alam di SMP Negeri 1.

Riduwan. 2016. Skala Pengukuran VariabelVariabel Penelitian. Jawa Barat: Alfabeta.

Riyanto, N. 2018. 7 Karya 1 Buku. Jawa Tengah: CV. Pelita Gemilang Sejatera (PGS).

Rukajat, A. 2018. Pendekatan Penelitian Kuantitatif: Quantitative Research Approach. Yogyakarta: Deepublish.

Siddik, Haji Abdulah. 1996. Sejarah Daerah Bengkulu 1500-1990. Jakarta: Balai Pustaka

Sugiyono. 2018. Metode Penelitiian Pendidikan Pendekatan Kuantitatif, Kaulitatif dan R\&D. Bandung: Alfabeta.

Yusuf, M. 2017. Metode Penelitian: Kuantitatif, Kualitatif dan Penelitian Gabungan. Jakarta: Prenada Media Group.

Widoyoko, Eko Putro. 2018. Teknik Penyusunan Instrumen Penelitian. Yogyakarta: Pustaka Belajar. 


\section{KETENTUAN PENULISAN ARTIKEL JURNAL KALPATARU}

1. Naskah berbahasa Indonesia yang disempurnakan bertemakan kesejarah yang meliputi hasil penelitian sejarah, pengajaran sejarah dan penelitian kebudayaan.

2. Naskah harus asli dan belum pernah dimuat dalam media lain. Naskah dapat berupa hasil penelitian/artikel kajian konseptual yang ditulis oleh perorangan dan atau kelompok.

3. Naskah ditulis dengan cara-cara yang sesuai dengan ketentuan penulisan artikel ilmiah menggunakan bahasa Indonesia yang baku, berupa ketikan, beserta soft file dalam CD-RW atau dengan mengirimkan email pada redaksi jurnal Kalpataru dengan alamat jurnalkalpatarusejarah@gmail.com, spasi tunggal, jenis huruf arial narrow ukuran 12, dengan panjang naskah antara 8-15 halaman pada kertas A4.

4. Artikel hasil penelitian memuat:

JUDUL

Nama Penulis

Abstrak

A. PENDAHULUAN

B. METODE PENELITIAN

C. HASIL DAN PEMBAHASAN

D. SIMPULAN

DAFTAR PUSTAKA
: XXX (HURUF KAPITAL)

: (disertai jabatan, institusi, dan email)

: (Bahasa Indonesia yang memuat 100-200 kata diikuti kata kunci, dengan jenis huruf arrial narrow dan ukuran huruf 11 serta dicetak miring).

: (memuat latar belakang masalah, tinjauan pustaka secara ringkas, masalah penelitian, dan tujuan penelitian).

: (berisi simpulan).

: (berisi pustaka yang dirujuk dalam uraian naskah).

5. Artikel Kajian Konseptual memuat:

\section{JUDUL Nama Penulis Abstrak \\ PENDAHULUAN \\ Sub Judul \\ Simpulan DAFTAR PUSTAKA}

: XXX (HURUF KAPITAL)

: (disertai jabatan, institusi, dan email)

: (Bahasa Indonesia yang memuat 100-200 kata diikuti kata kunci, dengan jenis huruf arrial narrow dan ukuran huruf 11 serta dicetak miring.

: (memuat latar belakang masalah, tinjauan pustaka secara ringkas, masalah penelitian, dan tujuan penelitian).

: Sesuai dengan kebutuhan (tanpa numbering).

: (berisi simpulan dan saran).

6. Referensi sumber dalam teks artikel ditulis dengan menggunakan side note, contoh (Jalaludin, 1991:79); sementara penulisan daftar pustaka disusun dengan ketentuan. Nama pengarang. Tahun terbit. Judul (dicetak miring). Kota terbit: Nama Penerbit. Contoh: Koentjaraningrat. 2010. Manusia dan Kebudayaan di Indonesia. Jakarta: Djambatan. Daftar pustaka hanya memuat pustaka/sumber yang dirujuk dalam uraian dan disusun menurut abjad tanpa nomor urut.

7. Naskah yang dimuat akan disunting kembali oleh redaksi tanpa mengubah isinya.

8. Naskah yang ditolak (tidak bisa dimuat) akan dikirim kembali ke penulis dengan pemberitahuan tertulis dari redaksi atau melalui email.

9. Penulis yang naskahnya dimuat akan mendapat 1 (satu) majalah nomor yang bersangkutan.

10.Kontak person: Muhamad Idris (081271498618); Eva Dina Chairunisa (082281267851); Jeki Sepriady (085269261780). 